\title{
WOMEN SCIENTISTS
}




\title{
WOMEN SCIENTISTS The Road to Liberation
}

\author{
Edited by \\ DEREK RICHTER
}

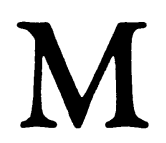


(C) The Contributors 1982

Softcover reprint of the hardcover 1st edition 1982 978-0-333-32468-4

All rights reserved. No part of this publication may be reproduced or transmitted, in any form or by any means, without permission.

First published 1982 by

THE MACMILLAN PRESS LTD

London and Basingstoke

Companies and representatives

throughout the world

Typeset in 11/12pt Baskerville by

STYLESET LIMITED

Salisbury, Wiltshire

ISBN 978-1-349-81344-5

ISBN 978-1-349-81342-1 (eBook)

DOI 10.1007/978-1-349-81342-1 


\section{Contents}

1. Opportunities for Women in Science 1 Derek Richter

2. Opportunities for Women Scientists in India Kamala Sohonie (India)

3. It Takes More Than Luck Marian W. Kies (United States)

4. Becoming an Anthropologist Chie Nakane (Japan)

5. The Wild Cat Liana Bolis (France and Italy)

6. The Achievement of Iranian Women in Science Tahereh M. Z. Rahmani (Iran)

7. Reflections on a Scientific Adventure

Rita Levi-Montalcini (Italy and United States)

8. Women Scientists in Sweden Inga Fischer-Hjalmars (Sweden)

9. A Little about Myself, and More about a More Important Matter - the Brain Natalia P. Bechtereva (USSR) 
10. Women in Cambridge Biochemistry

Dorothy Needham (United Kingdom)

11. The Progress of Science in Africa

W. Muta Maathai (Kenya)

12. Autobiography of an Unknown Woman

R. Rajalakshmi (India)

13. Conclusion

Nancy Seear (United Kingdom)

Index

\section{ACKNOWLEDGEMENTS}

The publishers are indebted to the United States Government for permission to publish the chapter by Dr Marion W. Kies.

We also thank Ing. Enrichetta Amour and the publishers AIDIA, for authorizing the inclusion in the chapter by Professor Rita Levi-Montalcini of material which previously appeared in the Proceedings of the Third International Conference of Women Scientists and Engineers. 